\title{
VEGETATION AND SOIL STRUCTURE AROUND BAGMATI RIVER NEAR SUNDARIJAL
}

\author{
Raiendra Basaula \\ Department of Zoology, Prithvi Narayan Campus, Pokhara, Nepal. \\ Email: basaular@pncampus.edu.np
}

\begin{abstract}
Vegetation samples in the form of herbarium and soil samples were collected from three stations of Bagmati river near the sundarijal. Vegetations were identified in Central Department of Botany. Frequency and relative frequency, density and relative density, dominance and relative dominance, important value index and biomass production of ground vegetation were determined. Castanopsis tribuloides was found dominant tree species. Soil samples of different stations were analyzed for different physical and chemical characters. in laboratory of Nepal Agriculture Research Council (NARC), in Khumaltar. The soil of study area was found acidic in nature. All collected soil samples were investigated
\end{abstract}

KEYWORDS. biomass, density, dominance, herbarium

\section{INTRODUCTION}

Environment is a complex of many things like light, temperature, soil, water etc. with all organisms. The relation of soil and vegetation has been a great interest to ecologists and several works have been carried out on soil and plant relationships. Vegetation distribution is influenced by the climatic factors and the edaphic factors i.e. soil. From the ecological point of view, the soil may be defined as the earth's crust which serve as a substratum for plant life. Soil is the weathered superficial layer of earth's crust which is mixed with living organisms and products of their decay (Daubenmire, 1959).

A true soil has five constituents: 1) the mineral particles of various sizes and in different stages of chemical decomposition; 2) organic matter in various stages of decomposition ranging from raw little to well decomposed humus; 3 ) the soil solution of various inorganic salts; 4) the soil air occupying interspaces not filled with soil solution and 5) micro-organisms, both plants and animals.(Weaver and Clements, 1938).
A definite relationship exists between the physical and chemical nature of the soil and vegetation distribution. Young (1934) suggested that heterogeneity in plant distribution is related to soil heterogeneity. Wild (1993) had shown that though climatic factors are responsible to a great extent for the boundaries of distribution of plant species, the main composition of forest stand is determined by nature of soil.

The physical characters determine the exact nature of the soil as a substratum of plants. The rigidity and supporting power, drainage and moisture storage capacity, plasticity, case of penetration by roots, aeration and reaction of plant nutrients are also intimately connected with the physical conditions of the soil (Forth 1984). The main objective of the current research is to analyze the vegetation and soil structure around Bagmati river, near Sundarijal, Kathmandu. 


\section{MATERIELS AND METHODS}

\section{Study Area}

Bagmati river originates in the southern strip of Shivapuri hill of Baghdwar, northern part of Kathmandu valley at an altitude of $2650 \mathrm{~m}$. The study area was selected at the surrounding of Sundarijal, which is the main feeding stream of Bagmati River. The study area was divided into main three stations.

Station $\mathrm{S}_{1}$ : The Station $\mathrm{S}_{1}$ was selected at the upper hill of Sundarijal. The station is situated near by Okhareni Gaun, at the height of $1900 \mathrm{~m}$. Station $\mathrm{S}_{2}$ : The Station $\mathrm{S}_{2}$ was selected near the Mahankal Gaun and Army Camp at the height of $1700 \mathrm{~m}$. This station is situated near the reservoir and it is about $1.5 \mathrm{~km}$ far from station $\mathrm{S}_{1}$. Station $\mathrm{S}_{3}$ : The Station $\mathrm{S}_{3}$ was selected below the hill of Sundarijal and Army Camp at the height of $1500 \mathrm{~m}$ and about $1.5 \mathrm{~km}$ far from station $\mathrm{S}_{2}$. The field work of present study was carried out between March 1999 to August 1999.

\section{Vegetation Analysis}

For the analysis of vegetation, a quadrat method was adopted. Five plots were taken at each station for random sampling and a quadrat size of $10 \mathrm{~m} \times 10 \mathrm{~m}$ was used. The tree species $(>10$ cbh) were recorded and their total counts were noted and kept for herbarium. The tree species were identified by consulting the Herbarium of Central Department of Botany, (TUCH) T.U. and National Herbarium Godavri (Kathmandu).

\section{i. Density and Relative Density}

Density is the number of individuals of a species per unit area or volume. By definition, density requires actual counts of individuals in a definite space. Density was calculated by using following equation.

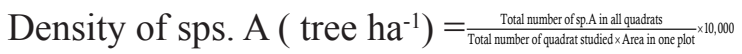
Relative density is the numerical strength of a species in relation to the total number of species. Relative Density of species A $=\frac{\text { Number of individual of sp. }}{\text { Total numbers of all species }} \times 100$ ii. Frequency and Relative Frequency

It is defined as the percentage of occurrence of a species in a series of samples of uniform size and contained in a single stand, the number and size of plants in each being ignored. Frequency was calculated by using formula;

Frequency $\%$ of sp. A $=\frac{\text { Number of plots with sp. } A}{\text { Total numbers of plots }} \times 100$ Relative frequency is the frequency of a species in relation to total frequencies of all species of that community. The formula is,

Relative frequency $=\frac{\text { Frequency of sp. A }}{\text { Sum of frequencies of all species }} \times 100$

\section{iii. Dominance and Relative Dominance}

Dominance or coverage indicates the amount of surface occupied by a plant in a community.

The circumference data of trees at $1.3 \mathrm{~m}$. height were used for calculating the basal area coverage by using the formula given by Zobel et al. (1987)

Basal Area $\mathrm{m}^{2}=\frac{\mathrm{C}^{2}}{4 \pi}$

Where $\mathrm{C}=$ Circumference

$$
\mathrm{Pie}=3.141633
$$

Dominance was calculated as;

Dominance $=\frac{\text { Total basal area }}{\text { Area sampled }}$

And Relative Dominance was calculated by using following formula;

Relative Dominance $=\frac{\text { Dominance for sp.A }}{\text { Total dominance for all sps. }} \times 100$

\section{iv. Importance Value Index (IVI)}

Since the quantitative values of frequency, density and cover was not sufficient for providing the total picture of the sociological characters of a species in a community, IVI was calculated for the individual sps. as;

IVI $=$ Relative frequency + Relative density + 
Relative dominance

\section{v. Biomass Production of Ground Vegetation}

For sampling of ground vegetation, a quadrate of size of $1 \mathrm{~m} \times 1 \mathrm{~m}$ was used. At each station five samplings were taken and all the ground vegetation were cut down from each plot and kept in polythene bags. All the samples were brought to the Central Department of Zoology, then dried in the oven for 24 hours at $70^{\circ} \mathrm{C}$, then the dry weight of ground vegetation was taken. The biomass of ground vegetation was estimated by following formula;

$$
\text { Biomass }=\frac{\text { Mean dry weight }}{\text { Area }}
$$

\section{Soil}

A general type of anger was used for sampling the soil. Five samples were collected at each station. Soil was taken from upper $20 \mathrm{~cm}$ of the soil surface. All the samples of single plot were kept separately in tightly closed polythene bags and taken to the laboratory for investigation.

The collected soil samples were investigated in laboratory of Nepal Agriculture Research Council (NARC), Soil Science Division, Agriculture Department, HMG, Khumaltar. Following chemical parameters of the soil were carried out;

Hydrogen ion concentration (pH), Organic matter (\%), Nitrogen (\%), Phosphorus (kg/ha), Potassium (kg/ha), Moisture content (\%) and Water holding capacity (\%)

\section{RESULTS}

\section{Vegetation Analysis}

A total of 19 tree species were recorded during study period. Among them, 118 individuals of sixteen tree species were recorded at station $\mathrm{S}_{1}$, 116 individuals of thirteen tree species were recorded at station $\mathrm{S}_{2}$ and 106 individuals of seven tree species were recorded at station $\mathrm{S}_{3}$.

\section{i. Frequency and Relative Frequency}

\section{Station $S_{1}$}

The highest frequency and relative frequency $100 \%$ and 9.25 of Quercus gluaca, Castonopsis tribuloids, Castanopsis indica, Rhododendron arboreum, Schima wallichi were found while the lowest frequency and relative frequency of Prunus cerrasoids were found $20 \%$ and $1.85 \%$ respectively.

\section{Station $S_{2}$}

The highest frequency and relative frequency $100 \%$ and $10.63 \%$ of Quercus glauca, Castanopsis tribuloids, Rhododendron arboreum, Schima wallichi and Castanopsis indica were found while the lowest frequency and relative frequency were found $20 \%$ and $2.12 \%$ of Machilus sps. and Myrica esculenta.

\section{Station $\mathrm{S}_{3}$}

The highest frequency and relative frequency $100 \%$ and 16.12 of Rhododendron arboreum,

Schima wallichi, Alnus nepalensis were found while the lowest frequency and relative frequency were found $40 \%$ and $6.65 \%$ of Machilus sps.

\section{ii. Density and Relative Density}

\section{Station $S_{1}$}

The highest density 500 no/ha of Castanopsis tribuloids was found which was followed by 280 no/ha of Schima wallichi, 240 no/ha of Rhododendron arboreum while lowest density was found 20 no/ha Prunus cerrasoids.

The highest relative density was $21.18 \%$ of Castanopsis tribuloids and lowest relative density was $0.84 \%$ of Prunus cerrasoids .

\section{Station $S_{2}$}

The highest density was 500no/ha of Rhododendron arboreum which was followed by $400 \mathrm{no} / \mathrm{ha}$ of Castanopsis tribuloids. The lowest density was 20 no/ha of Machilus spp. 
Vegetation and Soil Structure Around ...

and Myrica esculeneta. The highest relative density was 21.18 of Rhododendron arboretum and lowest relative density was 0.84 of Machilus spp. and Myrica esculeneta.

\section{Station $\boldsymbol{S}_{3}$}

The highest density was 460 no/ha of Castanopsis tribuloids, which was followed by $380 \mathrm{no} /$ ha of Pinus roxburghii and lowest density was $60 \mathrm{no} /$ ha of Machilus spp. The highest relative density was 21.69 of Castanopsis tribuloids and lowest relative density was 2.83 of Machilus spp.

\section{iii. Dominance and Relative Dominance}

\section{Station $S_{1}$}

The highest dominance was $9.7 \mathrm{~m}^{2}$ of Castanopsis tribuloids, which was followed by $7.6 \mathrm{~m}^{2}$ of Quercus lamellose and $7.3 \mathrm{~m}^{2}$ of Quercus glauca and Rhododendron arboreum. The lowest dominance was $1.3 \mathrm{~m}^{2}$ of Lindera spp.

The highest relative dominance was 13.41 of Castanopsis tribuloids and lowest relative dominance was 1.79 of Lindera spp.

\section{Station $S_{2}$}

The highest dominance was $10.5 \mathrm{~m}^{2}$ of Rhododendron arboreum, which was followed by $7.8 \mathrm{~m}^{2}$ of Castanopsis tribuloids. The lowest dominance was $0.6 \mathrm{~m}^{2}$ of Myrica esculeneta.

The highest relative dominance was 15.06 of Rhododendron arboreum and lowest relative dominance was 0.86 of Myrica esculeneta.

\section{Station $\boldsymbol{S}_{3}$}

The highest dominance was $13.5 \mathrm{~m}^{2}$ of Rhododendron arboreum, which was followed by $13.3 \mathrm{~m}^{2}$ of Castanopsis tribuloids. The lowest dominance was $3.5 \mathrm{~m}^{2}$ of Machilus spp.

The highest relative dominance was 19.04 of Rhododendron arboreum and lowest relative dominance was 4.93 of Machilus spp.

\section{iv. Important Value Index (IVI) Station $\mathbf{S}_{1}$}

The highest IVI was 43.84 of Castanopsis tribuloides which is followed by 30.51 of Schima wallichi. The lowest value was 5.05 of Prunus cerrasoides.

\section{Station $\mathbf{S}_{2}$}

The highest IVI was 14.19 of Rhododendron arboreum which is followed by 39.19 of Castanopsis tribuloides. The lowest value was 4.03 of Myrica esculeneta.

Station $\mathbf{S}_{3}$ The highest IVI was 56.56 of Castanopsis tribuloides which is followed by 50.25 of Rhododendron arboreum. The lowest value was 14.21 of Machilus spp.

\section{v. Biomass Production of Ground Vegetation $\left(\mathrm{gm} / \mathrm{m}^{2}\right)$}

The highest biomass production of ground vegetation was $270 \mathrm{gm} / \mathrm{m}^{2}$ at station $\mathrm{S}_{1}$ and lowest biomass production of ground vegetation was $150 \mathrm{gm} / \mathrm{m}^{2}$ at station $\mathrm{S}_{3}$. [Table-3].

\section{Soil}

Soil samples collected from different plots of three stations were analyzed for different physical and chemical characteristics.

In general the soil of the study area was sandy loam in nature. Composition of sand, silt and clay are shown in Table-4. In these plots of study area the percentage of sand alone covers more than $60 \%$.

Soil showed variation in colour at different station. Majority of soil sample at station $\mathrm{S}_{1}$ and $\mathrm{S}_{2}$ were black in colour. The colour ranged from light black to brown black and grayish black. The soil at station $\mathrm{S}_{3}$ was grayish black in colour. The highest moisture content of soil was $16 \%$ at station $\mathrm{S}_{1}$ and lowest was $6.03 \%$ at station $\mathrm{S}_{3}$. The water holding capacity of soil was maximum at station $\mathrm{S}_{1}$ of $45,2 \%$ and minimum at station $\mathrm{S}_{3}$ 
of $36.00 \%$.

Chemical parameters of soil include $\mathrm{pH}$, organic matter, nitrogen, phosphorus and potassium content.

Soil of study area was found acidic in nature. The highest $\mathrm{pH}$ of 6.7 was found at station $\mathrm{S}_{1}$ and lowest of 4.5 was found at station $\mathrm{S}_{2}$.

The organic matter content in soil was found increasing with the increase in altitude. It was maximum at station $\mathrm{S}_{1}(9.7 \%)$ and minimum at station $\mathrm{S}_{3}(1.932 \%)$.

Nitrogen content in soil of study area was maximum at station $\mathrm{S}_{1}(0.325 \%)$ and minimum at station $\mathrm{S}_{3}(0.180 \%)$. Phosphorus was found maximum at station $\mathrm{S}_{1}(32.5 \mathrm{~kg} / \mathrm{ha})$ and minimum at station $\mathrm{S}_{3}(21.72 \mathrm{~kg} / \mathrm{ha})$. Similarly Potassium was found maximum at station $\mathrm{S}_{1}(200.80 \mathrm{~kg} / \mathrm{ha})$ and minimum at station $\mathrm{S}_{3}(122.00 \mathrm{~kg} / \mathrm{ha})$.

Table-1. Total tree species of the Bagmati Watershed Area during study period.

\begin{tabular}{|c|c|c|c|c|c|}
\hline \multirow[t]{2}{*}{ Name of tree sps. } & \multirow[t]{2}{*}{ Local name } & \multirow[t]{2}{*}{ Family } & \multirow[b]{2}{*}{$\mathrm{S}_{1}$} & \multicolumn{2}{|c|}{ Station } \\
\hline & & & & $\mathrm{S}_{2}$ & $\mathrm{~S}_{3}$ \\
\hline Quercus lanata (Smith) & Banjh & Fagaceae & + & - & - \\
\hline Quercus glauca (Thunb) & Musure falant & Fagaceae & + & + & - \\
\hline Quercus lamaellosa (Smith in Rees) & Banse falant & Fagaceae & + & + & - \\
\hline Quercus semecarpifolia (Smith) & Kharsu & Fagaceae & + & - & - \\
\hline Castonopsis tribuloids (Sm) A.DC. & Masure katus & Fagaceae & + & + & + \\
\hline Castonopsis indica (Roxb)A.DC. & Dhale katus & Fagaceae & + & + & + \\
\hline Rhodendron arboreum & & Ericaceae & + & + & + \\
\hline Lyonia ovalifolia (Wallich) Drude in Engl. & Angeri & Ericaceae & + & + & - \\
\hline Schima wallichi (D.C.) & Chilaune & Theaceae & + & + & + \\
\hline Cinnamomum sps. & Masala & Lauraceae & + & - & - \\
\hline Prunus cerrasoids ( D.Don) & Paiyu & Betulaceae & + & - & - \\
\hline Myrica esculanata (D.Don) & Hande kafal & Myricaceae & + & + & - \\
\hline Myrsine capitellata (Wall) & Seti kath & Myricaceae & + & - & - \\
\hline Linder sps. & & Lauraceae & + & - & - \\
\hline Pinus roxburghii (Sagent) & Ram sallo & Pinaceae & + & + & + \\
\hline Litsea oblonga (Wall) & Paheli & Lauraceae & - & + & - \\
\hline Machilus sps. & & Lauraceae & - & + & + \\
\hline Lindera pulcherima (Nees) & Phusure & Lauraceae & - & + & - \\
\hline Alnus nepalensis (D.Don) & Utis & Betulaceae & - & + & + \\
\hline
\end{tabular}

+ Present - Absent 
Vegetation and Soil Structure Around ...

Table-2. Density, Relative Density, Frequency, Relative Frequency, Dominance, Relative Dominance, and Important Value Index of tree species found in Study Area.

Station $\mathrm{S}_{1}$

\begin{tabular}{llllllll}
\hline Name of the plants & Density/ha & $\mathrm{RD}$ & $\mathrm{F} \%$ & $\mathrm{RF}$ & Dominance/m & RD & IVI \\
\hline Quercus lanata & 140 & 5.93 & 80 & 7.40 & 6.9 & 9.54 & 22.87 \\
Quercus glauca & 240 & 10.16 & 100 & 9.25 & 7.3 & 10.09 & 29.5 \\
Quercus lamellosa & 140 & 5.93 & 80 & 7.40 & 7.6 & 10.51 & 23.84 \\
Quercus semecarpifollia & 80 & 3.38 & 60 & 5.55 & 5.2 & 7.19 & 16.12 \\
Castonopsis semecarpifolia & 500 & 21.18 & 100 & 9.25 & 9.7 & 13.41 & 43.84 \\
Castonopsis indica & 160 & 6.77 & 100 & 9.25 & 5.2 & 7.19 & 23.21 \\
Rhododendron arboreum & 240 & 10.16 & 100 & 9.25 & 7.3 & 10.09 & 29.5 \\
Lyonia ovalifolia & 180 & 7.62 & 80 & 7.40 & 4.5 & 6.22 & 21.94 \\
Schima wallichi & 280 & 11.86 & 100 & 9.25 & 6.8 & 9.40 & 30.51 \\
Cinnamomum sps. & 100 & 4.23 & 60 & 5.55 & 2.6 & 3.59 & 13.37 \\
Prunus cerassoids & 20 & 0.84 & 20 & 1.85 & 1.7 & 2.35 & 5.05 \\
Myrica esculenta & 60 & 2.54 & 40 & 3.70 & 1.9 & 2.62 & 8.86 \\
Myrsine capitellata & 100 & 4.23 & 60 & 5.55 & 2.2 & 3.04 & 12.82 \\
Linder sps. & 40 & 1.69 & 40 & 3.70 & 1.3 & 1.79 & 7.18 \\
Pinus roxburghii & 80 & 3.38 & 60 & 5.55 & 2.1 & 2.90 & 11.83 \\
\hline
\end{tabular}

Station $\mathrm{S}_{2}$

\begin{tabular}{llllllll}
\hline Name of the plants & Density/ha & $\mathrm{RD}$ & $\mathrm{F} \%$ & $\mathrm{RF}$ & Dominance/m $^{2}$ & $\mathrm{RD}$ & IVI \\
\hline Quercus glauca & 180 & 7.62 & 100 & 10.63 & 6.2 & 8.89 & 26.63 \\
Quercus lamellosa & 140 & 5.93 & 80 & 8.51 & 6.3 & 9.03 & 23.02 \\
Castonopsis tribuloids & 400 & 16.94 & 100 & 10.63 & 7.8 & 11.19 & 38.19 \\
Rhododendron arboreum & 500 & 21.18 & 100 & 10.63 & 10.5 & 15.06 & 46.19 \\
Lyonia ovalifolia & 160 & 6.77 & 80 & 8.51 & 7.5 & 10.76 & 25.53 \\
Schima wallichi & 220 & 9.32 & 100 & 1063 & 7.2 & 10.32 & 29.74 \\
Machilus sps. & 20 & 0.84 & 20 & 2.12 & 1.7 & 2.43 & 5.28 \\
Litsea oblonga & 40 & 1.69 & 40 & 4.25 & 1.3 & 1.86 & 7.67 \\
Lindera pulcherima & 60 & 2.54 & 40 & 4.25 & 2.1 & 3.01 & 9.64 \\
Castonopsis indica & 180 & 7.62 & 100 & 1063 & 6.3 & 9.07 & 26.79 \\
Alnus nepalensis & 200 & 8.47 & 80 & 8.51 & 6.1 & 8.75 & 25.28 \\
Myrica esculenta & 20 & 0.84 & 10 & 2.12 & 0.6 & 0.86 & 4.03 \\
Pinus roxburghii & 200 & 8.47 & 80 & 8.51 & 6.1 & 8.75 & 25.97 \\
\hline
\end{tabular}


Station $\mathrm{S}_{3}$

\begin{tabular}{llllllll}
\hline Name of the plants & Density/ha & RD & F\% & RF & Dominance/m & RD & IVI \\
\hline Rhododendron arboreum & 320 & 15.09 & 100 & 16.12 & 13.5 & 19.04 & 50.25 \\
Schima wallichi & 300 & 14.15 & 100 & 16.12 & 12.2 & 17.20 & 47.47 \\
Castonopsis tribuloids & 460 & 21.69 & 100 & 16.12 & 13.3 & 18.75 & 56.56 \\
Castonopsis indica & 200 & 9.43 & 80 & 12.90 & 8.6 & 12.12 & 34.45 \\
Alnus nepalensis & 400 & 18.86 & 100 & 16.12 & 9.7 & 13.68 & 48.66 \\
Machilus sps. & 60 & 2.86 & 40 & 6.45 & 3.5 & 4.93 & 14.21 \\
Pinus roxburghii & 380 & 17.92 & 100 & 16.12 & 10.1 & 14.24 & 48.28 \\
\hline
\end{tabular}

Table-3. Biomass production of ground vegetation

\begin{tabular}{cc}
\hline Stations & Biomass production $\mathrm{gm} / \mathrm{m}^{2}$ \\
\hline $\mathrm{S}_{1}$ & 270 \\
$\mathrm{~S}_{2}$ & 256 \\
$\mathrm{~S}_{3}$ & 150 \\
\hline
\end{tabular}

Table-4. Physical properties of soil of study area Station $\mathrm{S}_{1}$

\begin{tabular}{|c|c|c|c|c|}
\hline $\begin{array}{c}\text { Sand } \\
\%\end{array}$ & $\begin{array}{l}\text { Silt } \\
\%\end{array}$ & $\begin{array}{c}\text { Clay } \\
\%\end{array}$ & $\begin{array}{c}\text { Silt }+ \\
\text { Clay \% }\end{array}$ & $\begin{array}{c}\text { Moisture } \\
\text { Content \% }\end{array}$ \\
\hline 69 & 21 & 13 & 34 & 16 \\
\hline 76 & 24 & 12 & 36 & 15 \\
\hline 66 & 27 & 9 & 36 & 12.2 \\
\hline 70 & 23 & 8 & 31 & 12.01 \\
\hline 72 & 23 & 10 & 33 & 11.0 \\
\hline \multicolumn{5}{|c|}{ Station $\mathrm{S}_{2}$} \\
\hline $\begin{array}{c}\text { Sand } \\
\%\end{array}$ & $\begin{array}{c}\text { Silt } \\
\%\end{array}$ & $\begin{array}{c}\text { Clay } \\
\%\end{array}$ & $\begin{array}{c}\text { Silt }+ \\
\text { Clay \% } \\
\end{array}$ & $\begin{array}{c}\text { Moisture } \\
\text { Content \% } \\
\end{array}$ \\
\hline 65 & 24 & 13 & 37 & 11.2 \\
\hline 63 & 25 & 15 & 40 & 11.5 \\
\hline 68 & 26 & 10 & 36 & 12.0 \\
\hline 69 & 29 & 11 & 40 & 10.02 \\
\hline 74 & 21 & 9 & 30 & 9.8 \\
\hline
\end{tabular}

Station $\mathrm{S}_{3}$

\begin{tabular}{ccccc}
\hline $\begin{array}{c}\text { Sand } \\
\%\end{array}$ & $\begin{array}{c}\text { Silt } \\
\%\end{array}$ & $\begin{array}{c}\text { Clay } \\
\%\end{array}$ & $\begin{array}{c}\text { Silt+ } \\
\text { Clay \% }\end{array}$ & $\begin{array}{c}\text { Moisture } \\
\text { Content \% }\end{array}$ \\
\hline 61 & 25 & 6 & 31 & 7.5 \\
67 & 13 & 9 & 22 & 8.6 \\
68 & 17 & 11 & 28 & 9.0 \\
71 & 20 & 7 & 27 & 7.2 \\
70 & 22 & 8 & 30 & 6.03 \\
\hline
\end{tabular}

\section{DISCUSSION}

Present study showed that diversity of tree species was comparatively higher at station S1 than at other stations. Castanopsis tribuloides was found dominant tree species, and other dominant species were Rhododendron arboreum and Schima wallichi. So Schima-Castanopsis type of forest was found in the study area. The range of density of individual species were found between 200-500. At station $S_{1}$ the dominance of tree species was found in decreasing order as Castanopsis tribuloids > Schima wallichi $>$ Rhododendron arboreum. At station $\mathrm{S}_{2}$ it was Rhododendron arboreum $>$ Castanopsis tribuloids $>$ Machillus species and at station $\mathrm{S}_{3}$, it was Castonopsis tribuloids $>$ Pinus roxburghii $>$ Machillus spp.

Frequency analysis gives the uniformity of the species. The frequency wa $100 \%$ of Quercus glauca, Castonopsis tribuloides, Castanopsis indica, Rhododendron species and Schima 
wallichi at station $\mathrm{S}_{1}$. The frequency was $100 \%$ of Quercus glauca, Rhododendron species, Schima wallichi and, Castanopsis indica at station $\mathrm{S}_{2}$. Castanopsis tribuliodes and Alnus nepalensis showed 100\% frequency at station $\mathrm{S}_{3}$. (Table-2). The forest was found sparse type at station $\mathrm{S}_{3}$ but it was comparatively dense at stations $\mathrm{S}_{1}$ and $\mathrm{S}_{2}$, it may be due to the deforestation and grazing at station $\mathrm{S}_{3}$.

The moisture showed its influence on the nutrient content of the soil. The increase in soil moisture causes the dilution of $\mathrm{H}^{+}$ions in the soil solution which in turn rises the $\mathrm{pH}$. The nutrient content in the organic matter is released by the microbial activities, for which moisture is necessary. As moisture increases, there is increment in the nutrient content of the soil. Moisture content in soil was low at station $\mathrm{S}_{3}$ and high at station $\mathrm{S}_{1}$. (Table-4)

The soil of study area was found acidic in nature. The $\mathrm{pH}$ of soil was comparatively low at station $\mathrm{S}_{3}$ than at $\mathrm{S}_{2}$ and $\mathrm{S}_{1}$ (Table 5), it may be due to low moisture content.

Prajapati (1976) made an analytical study on the effect of nutrition (N,P,K), temperature and light on the growth and development of chir-pine seedlings. Shrestha (1979 made on ecological study on ground vegetation of Sallaghari hill in relation to its soil. Comparison of floristic composition at ground level of the northern and southern portion of hill and the analysis of soil characters (texture, $\mathrm{pH}$, moisture content and nutrient content) revealed that such differences in the vegetation distribution were attributable to the variations in edaphic factors.

Manandhar and Bajracharya (1992) analyzed the surface soil characteristics in different ecological stand of mixed hard wood forest of Nagarjun hill. They observed that soils from Quercus dominated stand possessed low moisture, $\mathrm{pH}$ and nitrogen but high organic matter content compared to the stands possessing Machilus species.

Rana Chhetri (1981) analyzed the woody vegetation in relation to altitude, slope and soil factors in Chandragiri. In this study within the altitudinal range from $1380 \mathrm{~m}$ to $2510 \mathrm{~m}$, four distinct kinds of forests were found on the basis of species composition. He reported that, the distribution of the forest types were governed by soil characters, such as texture, $\mathrm{pH}$, organic matter content etc. along with the topographic features.

Young (1934) made a complete analysis of soil and vegetation in certain area of Cranberry lake region which included climax forest and other natural vegetation. The soil in climax forest habitats were richer in soil parameters, compared to the habitats supporting less developed vegetation. The result of analysis showed that a high degree of heterogeneity prevailed from habitat to habitat and similarly vegetation composition also varied. On the basis of this result, he concluded that soil heterogeneity is correlated with the plant heterogeneity.

Gazizullin (1997) studied the inter-relationship between soil topography and forest vegetation within the zone of mixed broad leaved forests of the middle Volga region. They showed the forest composition and productivity are influenced by the nature of the soil.

As the content of organic matter in the soil increases, the content of nitrogen and phosphorus also increases. The nitrogen and phosphorus content of soil low at station $\mathrm{S}_{3}$ than at $\mathrm{S}_{2}$ and $\mathrm{S}_{1}$; it may be due to low organic matter content in soil at station $\mathrm{S}_{3}$. The potassium content of soil in the study area was higher at station S1 and lower at station $\mathrm{S}_{3}$, it may be due to the higher organic matter content and moisture content at station $\mathrm{S}_{1}$.

The biomass of ground vegetation was highest 
at station S1, it may be due to the high quantity of nitrogen, phosphorus, moisture and organic matter content in the soil of that area. Jha and Upadhaya (1982) showed the chemical composition of the soil, were directly related with climatic conditions. The low biomass production of ground vegetation at station $\mathrm{S}_{3}$ may be due to grazing of cattle and human exploitation in that area.

\section{ACKNOWLEDGEMENT}

I am grateful to my respectable supervisor Prof. Dr. Umakanta Ray Yadav Central Department of Zoology, for his valuable suggestions and encouragement. I am extremely grateful to Soil Science Division of Nepal Agriculture Research Council for providing necessary lab facilities. I would like to thank National Herbarium Godavari, Kathmandu and Central Herbarium TU, Botany (TUCH) for the identification of plants.

\section{REFERENCES}

Daubenmire, R.F. (1959). Plants and Environment: A text book of plant Autecology, (2 ${ }^{\text {nd }}$ ed.) New York: Jhon Wiley and Sons Inc.

Forth, H.D. (1984). Fundamental of Soil Science, ( $7^{\text {th }}$ ed.) New York: Jhon Wiley and Sons Inc. Gazizullin, A.K. (1997). Interrelations of soil and forest vegetations in middle Volga Region, Biological Abstracts, 103:11.

Jha, S. and A. Upadhaya, (1982). A Preliminary study of the Climoedaphic Interrelation in the Terai, Procecding of First Science and Technology Congress, NCST.
Manandhar G. and D. Bajracharya, (1992). Surface soil characteristics in different ecological stands of Nagarjun Hill, Proceedings of first national botanical conference.

Prajapati, K. (1976). Growth and development of chirpine seedlings in relation to nutrition, temperature and light", unpublished M.Sc. Dessertation, Australian National University.

Rana Chhetry, M. B. (1981). Ecological and floristic studies on some adjoining forests of Chandragiri", unpublished M.Sc. Dessertation T.U. Nepal.

Shrestha, R.B. (1979). An ecological study of the ground vegetation of Sallaghari Hill, Godawari, in relation to its soil complex, unpublished M.Sc. Dissertation, Tribhuwan University.

Wild, S.A. (1993). The Relations of Soil and Forest Vegetations of Lake state Region, Ecology, 14: 94-105.

Young, V.A. (1934). Plant Distribution as influenced by Soil Heterogeneity in Craberry Lake Region of the Adirondack Mountains, Ecology 15(2):154-195

Zobel, D.B., P.K. Jha, M.J. Behon, and U.K.R. Yadav (1987). A Practical Manal for ecology. Ratna Book distributors, Kathmandu, Nepal.

(Received 8 May 2017, revised accepted 21 Aug 2017) 